Article

\title{
Platy Galena from the Viburnum Trend, Southeast Missouri: Character, Mine Distribution, Paragenetic Position, Trace Element Content, Nature of Twinning, and Conditions of Formation
}

\author{
Richard D. Hagni \\ Department of Geological Sciences and Geological and Petroleum Engineering, Missouri University of Science \\ and Technology, Rolla, MO 65401, USA; rhagni@mst.edu
}

Received: 15 December 2017; Accepted: 23 February 2018; Published: 2 March 2018

\begin{abstract}
The Viburnum Trend of southeast Missouri is one of the world's largest producers of lead. The lead occurs as galena, predominantly in two crystallographic forms, octahedrons and cubes. Many studies have shown that octahedral galena is paragentically early, the more abundant of the two crystal forms, and is commonly modified in the cube. Those studies also have shown that the cubic form is paragenetically later, less abundant than the octahedrons, and may exhibit minor octahedral modifications. Viburnum Trend galena crystals that exhibit a platy form have received almost no study. The reason for their lack of study is the rarity of their occurrence. This communication discusses their character, mine distribution, paragenetic position, trace element contents, nature of twinning, and speculated conditions of formation. It also compares their character to similar platy galena occurrences in Germany, Bulgaria, Russia, Mexico, and notes their occurrence at the Pine Point District in the Northwest Territories of Canada and at the Black Cloud mine in Colorado. Flat, platy galena crystals have been recognized to occur in very small amounts in the Magmont, Buick, Fletcher, Brushy Creek, and Sweetwater mines in the Viburnum Trend. In contrast, platy galena has never been observed to occur at the Casteel, West Fork, \#27, \#28, and \#29 mines in the Trend. The platy crystals have formed early in the paragenetic sequence of the ores, prior to and coated by subsequently deposited druzy quartz and cubic galena. Spinel twinning of the octahedron produces flat platy crystals. The platy galena crystals of the Viburnum Trend are very similar in crystal morphology to platy galena crystals interpreted to be spinel twins in the Gonderbach Ag mine in NW Germany, the Dalnegorsk Pb-Zn (skarn deposit) mine in SE Russia, the Madan ore field of skarn $\mathrm{Pb}-\mathrm{Zn}-\mathrm{Ag}$ deposits of southern Bulgaria, and the large Naica skarn $\mathrm{Pb}$ mine of northern Mexico. The crystallization of certain crystal forms of galena has been ascribed to the incorporation of elevated contents of trace elements in some lead districts. Analysis of Viburnum platy galena crystals shows that they contain very low levels of trace elements: $3.1 \mathrm{ppm} \mathrm{Ag},<2 \mathrm{ppm} \mathrm{Bi}$, $<2 \mathrm{ppm} \mathrm{Sb}$, and $<2 \mathrm{ppm}$ As. Thus, elevated trace element content is not the cause for the development of Viburnum platy galena. It is speculated that the Viburnum spinel-twinned galena crystals were the result of rapid crystallization from oversaturated hydrothermal ore fluids.
\end{abstract}

Keywords: galena; morphology; spinel twins; trace elements; paragenesis; Viburnum Trend; Missouri

\section{Introduction}

The Viburnum Trend of the Southeast Missouri Lead District was the world's largest lead-producing district for nearly half a century, and today remains a very significant lead producer. Present mining in the Southeast Missouri Lead District occurs in six mines located in the Viburnum Trend District (Figure 1). Prior to 1964, production came from the Old Lead Belt and it was the world's 
leading producer of lead. Although the Old Lead Belt has been closed for a long time, an ore deposit has been drilled at the Higden deposit in the Fredericktown subdistrict and has been considered for possible mining. Lead was first discovered in the Viburnum Trend in 1955, and mining began in the new trend at the Viburnum 27 mine in 1960. The lead in the district occurs as galena (PbS). The galena in the district has been deposited in two forms: (1) early main-stage octahedrons, and (2) later cubes. Both forms exhibit minor modifications of the other form.

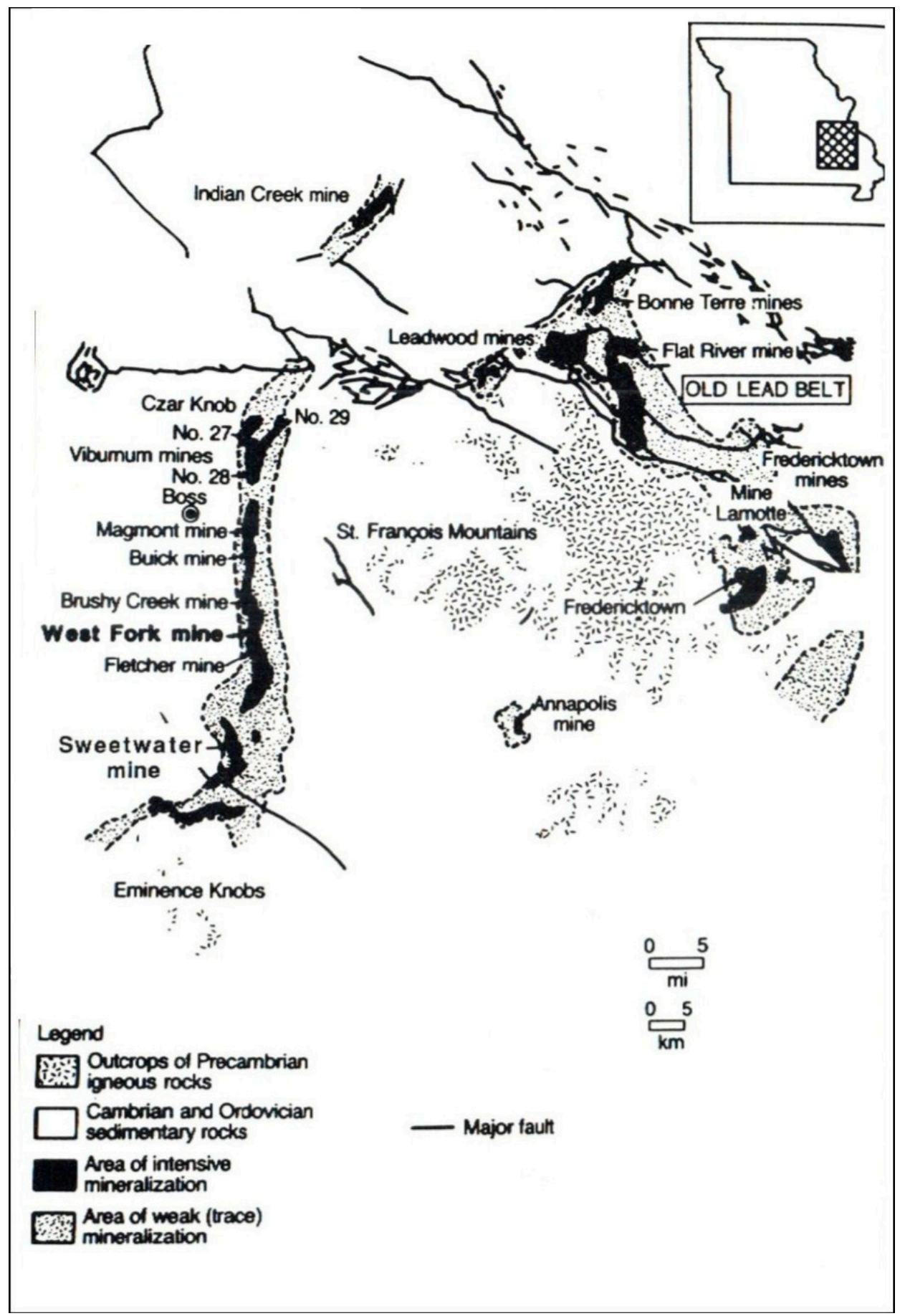

Figure 1. The Southeast Missouri mining district (after Mavrogenes [1] modified from Kisvarsanyi, [2]). The Old Lead District is located to the northeast of the Precambrian rock exposures, and the Viburnum Trend runs north-south along the west side of the Precambrian exposures. 


\section{General Geology of the Viburnum Trend}

The Viburnum Trend of the Southeast Missouri Lead District is about 45 miles long, extending in an essentially north-south direction. The Trend has encompassed as many as 11 mines, and currently is considered to involve six active mines. All of the ore deposits mined are classical Mississippi Valley-type (MVT) deposits formed from low-temperature fluids unrelated to igneous activity, and the ores are deposited in sedimentary rocks. The ores are epigenetic and have been deposited largely in the Cambrian Bonneterre Formation, especially in the upper portion of the Bonneteere, but some ores also occur in the underlying Cambrian Lamotte Sandstone and alteration along with minor mineralization is locally present in the overlying Cambrian Davis Shale. The presence of unusual early ore deposition throughout much of the stratigraphic interval has recently been recognized and described at the Brushy Creek mine [3] The localization of the ore deposits within the Bonneterre Fornation is closely controlled by the reef and grainstone sedimentary facies of that formation [4] and by the position of the pinchout of the underlying Lamotte Formation.

The origin of the mineralizing ore fluids has generally been speculated to involve evaporated seawater that was generated in the Arbuckle and related sedimentary basins to the south of the Trend. Those fluids were propelled northward by large-scale tectonic activity, probably topographically by rising elevations in the source areas, during the late Pennsylvanian-Permian time [5-8].

The mineralization of the Viburnum Trend is characterized by a relatively complex paragenetic sequence in which repeated deposition of sulfide minerals in multiple pulses caused sphalerite to be deposited during five periods and galena during seven periods [9] The temperature interval of deposition is best constrained by fluid inclusion measurements for sphalerite crystals from various paragenetic positions. Those measurements indicate a temperature range of ore deposition from $137^{\circ} \mathrm{C}$ down to $80^{\circ} \mathrm{C}$ [10]. Early black sphalerite, which could not be measured, probably formed at temperatures slightly above $137^{\circ} \mathrm{C}$, and post-sphalerite calcite formed at temperatures below $80^{\circ} \mathrm{C}$. Salinity measurements for sphalerite fluid inclusions show that the ore fluids were brines with about $20-30 \% \mathrm{NaCl}$ equivalent. Recent thermodynamic calculations, together with ICP-MS analyses of fluid inclusions in what has been judged to be ore-stage calcite crystals from midcontinent MVT ore deposits, indicates that the concentrations of zinc, and probably other metals such as lead, were on the order of magnitude of about 1-10 ppm, amounts that would be expected for sedimentary brines [11]. The metal-bearing brines probably deposited the ore sulfides upon encountering sulfur at the sites of deposition in the form of sulfur-bearing fluids, sulfur in organic matter, and sulfur in framboidal sedimentary pyrite. Strontium isotope measurements for fluid inclusions mainly in sulfide minerals from the Viburnum Trend do not support a model of ore deposition from a single fluid [12].

Typical ores in the Viburnum Trend involve sulfides that are disseminated replacements of host rock dolomite. Locally the ore minerals crystallize in vugs to form open-space linings that are characterized by euhedral sulfide crystals together with euhedral gangue quartz and dolomite crystals. The rare euhedral platy galena crystals of the present study occur in these open-space linings. The sulfide minerals in most all disseminations and open-space linings are predominately galena and sphalerite. Chalcopyrite, marcasite, pyrite, siegenite, and bravoite are present in smaller variable amounts.

The Viburnum Trend differs from most other MVT districts in being lead-rich rather than zinc-rich. In contrast to the Tri-State MVT district of southwest Missouri, northeast Oklahoma, and southeast Kansas, for example, with a zinc:lead ratio of 4.1, the southeast Missouri district has a lead: zinc ratio greater than 5.1 [13]. This probably is the result of the ore fluids reaching the Precambrian basement in the Viburnum Trend where they leached lead from trace lead-bearing feldspar as well as locally from Precambrian ore deposits such as the Boss-Bixby Cu-Fe deposit [13]. The Viburnum ores are totally devoid of barite, but nearby a significant formerly-producing Washington County barite district occurs in stratigraphically younger host rocks and it may be genetically related to the ores in the Viburnum Trend. The Washington County barite ores contain significant amounts of galena. 
The crystal size of Viburnum sulfide minerals is characteristically large, a factor that facilitates mineral separation at the mills and makes determinations of paragenetic sequence of mineral deposition viable. In contrast, very local, rare occurrences of bornite-rich pods form massive replacements of host dolomite and are composed of very fine-grained bornite, chalcopyrite and a variety of copper-cobalt-nickel-arsenic minerals that are highly unusual for MVT deposits [13-15]. These ores consist of nearly $100 \%$ sulfides with little or no remaining unreplaced dolomite; they were formed distinctly before the lead-zinc ores, and they are almost always totally separate from those ores. These ores require ore microscopy to determine their mineralogy [13-15]. A total of only eight small bornite pods have been discovered in the trend.

Finally, another rare occurrence of exceptionally fine-grained ores is that of a lesser number of mostly stratiform massive galena-sphalerite-chalcopyrite pods and especially strata-bound lenses that occur locally as replacements of shaly portions of the Bonneterre Dolomite [16,17]. They are physically separate from the fine-grained massive bornite pods. They also absolutely require ore microscopic examination to ascertain their mineralogy.

Examination of ore-stage euhedral rhombic Viburnum Trend dolomite by cathodoluminescence microsopy (CLM) has shown that it was deposited during four distinct periods, and that these four periods are present essentially throughout essentially the entire Viburnum Trend [18]. Importantly, it was subsequently shown that the dolomite crystal CL zoning overlapped sulfide ore mineral deposition [19]. Those studies indicated that the ore fluids were not confined to each mine, but rather they had circulated freely throughout the entire Viburnum Trend. Continued study of secondary dolomite by CLM outside the Viburnum Trend has shown that those four zones are present throughout much of southern Missouri and provide important confirming evidence that the ore-depositing fluids were not even restricted to the Viburnum Trend but that they had traveled over a wide regional extent $[20,21]$.

\section{Previous Investigations of Viburnum Galena Morphology}

Many studies of Viburnum galena octahedrons and cubes have been conducted over past three or more decades. A few of those studies can be cited here. Octahedral galena (Figure 2) formed early in the paragenetic sequence of mineral deposition, and cubic galena (Figure 3) formed late. Most studies have noted that galena octahedrons are much more abundant than galena cubes [9,14,22-27]. Studies of mineral paragenetic sequence of deposition have shown that the octahedrons were deposited prior to cubic galena $[9,22-25,28]$. Octahedral galena was repeatedly deposited at least six times throughout the paragenetic sequence $[9,22]$. Octahedral galena commonly is etched by fluids that were out of equilibrium with the earlier deposited galena prior to the deposition of cubic galena $[9,22]$. The fact that the earlier deposited octahedral galena had ceased deposition and that those galena crystals were instead being dissolved indicates that the fluids at this point in time were out of equilibrium with respect to the deposition of galena. Octahedrons exhibit cubic modifications that vary in extent with their positions within ore trends $[29,30]$. Cubic galena has been deposited twice, and both generations occurred after the deposition of galena octahedrons [9]. Mine geologists have commonly noted that galena cubes are more abundant in mine areas where the galena octahedrons are heavily leached.

An unusual form of galena that is rare in the Viburnum Trend is that which exhibits a dendritic form. Clendenin [31] and Clendenin and Rickman [32] have discussed the occurrence of dendritic galena at the Sweetwater mine (formerly Ozark Lead mine) in the Viburnum Trend and have interpreted the several textural variations of dendritic galena to be the result of different extents of oversaturation of the ore fluids. Mavrogenes et al. [1] described dendritic galena intergrown with colloform sphalerite in the West Fork mine in the Trend and also interpreted its formation to be the result of oversaturation of the ore fluid with respect to sulfur. Sun et al. [17] described skeletal dendritic galena intergrown with skeletal dendritic chalcopyrite in unusual exceptionally fine-grained lead-rich massive ores, called steel galena by mine geologists (the massive galena with no evident distinct grains looks like steel to the naked eye), at the Casteel and Viburnum 29 mines. The massive finely crystalline 
steel galena ores clearly have formed by rapid crystallization from oversaturated ore fluids. All of these occurrences of dendritic galena appear to be unusual variations of cubic galena where it formed by rapid crystallization from oversaturated ore fluids.

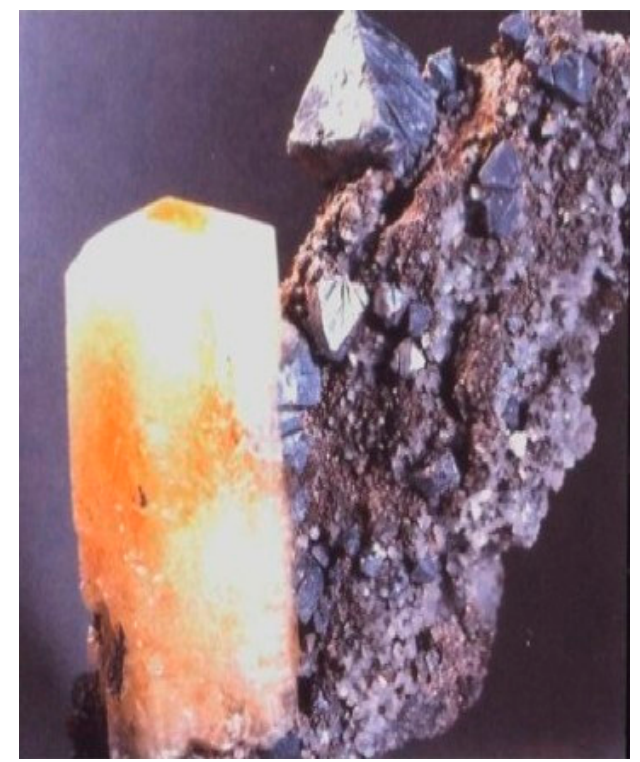

Figure 2. Octahedral galena deposited in open space and partly covered by later calcite. The largest octahedron is about $2 \mathrm{~cm}$ across and has a small cubic modification.

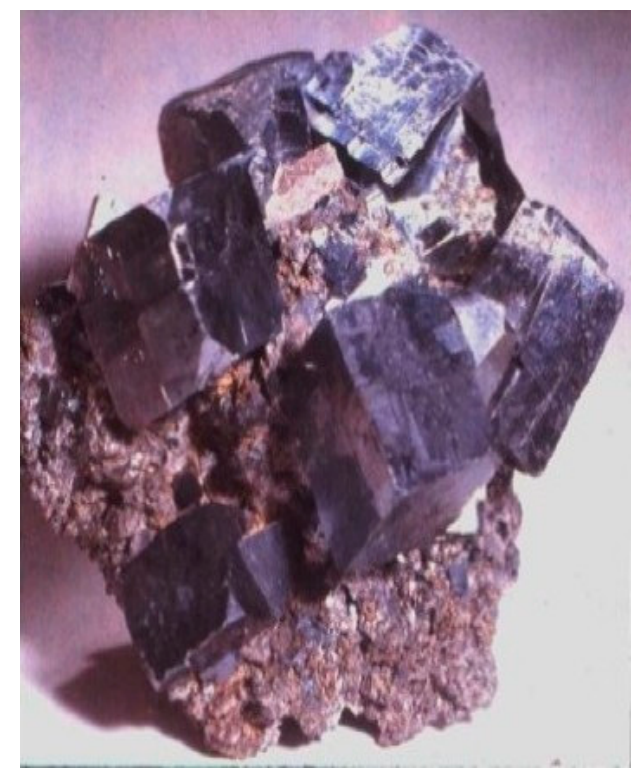

Figure 3. Cubic galena deposited in open space. The cubes are about $2 \mathrm{~cm}$ across and some have small octahedral modifications at their corners.

\section{Platy Galena in the Viburnum Trend}

Euhedral crystals of platy galena are extremely rare in the Viburnum Trend. It is so rare that some mine geologists in the Trend indicate that they have never seen platy galena crystals. Viburnum platy galena has not been the subject of any previous scientific study, and no papers have been published on such crystals in the Trend, in fact, they have never even been mentioned in a previous paper. 
Galena should form equidimensional isometric crystals rather than flat platy crystals. This raises two questions: (1) What crystal form do the galena plates represent? and (2) What were the conditions of the ore fluids that caused platy galena to be deposited?

Platy galena crystals are extremely rare in the Viburnum Trend, and have only been found very locally in some of the mines. No previous study has been conducted to determine their character, paragenetic position, trace element content, and distribution with respect to mines, or to speculate on conditions of the ore fluids at the time of their deposition.

\section{Present Study of Viburnum Platy Galena}

The present study of Viburnum platy galena began a few years ago when the writer acquired a single large lead ore specimen from the Magmont mine in the Viburnum Trend that contained an astonishing number of platy galena crystals. The specimen was collected by the late Pete Sweeney when he was chief geologist at the Magmont mine. The specimen is $13 \mathrm{~cm}$ across, weighs about 20 pounds, and exhibits 60 plates of galena partly intergrown with quartz and cubic galena (Figure 4).

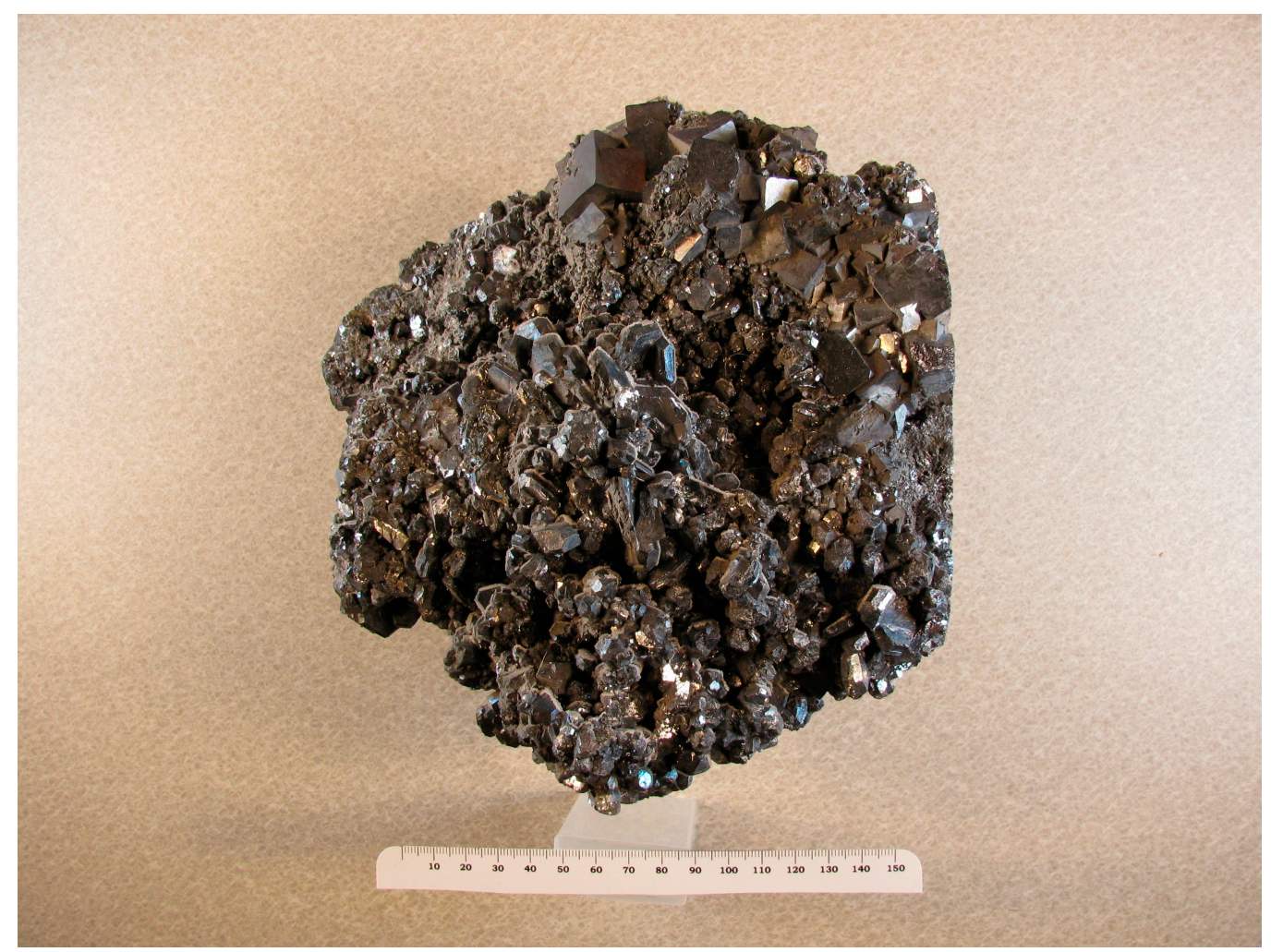

Figure 4. Unusual galena specimen from the Magmont mine that contains 60 platy galena crystals. The specimen is about $13 \mathrm{~cm}$ across and weighs 20 pounds. Specimen collected by Pete Sweeney.

Interestingly, the arrival of that specimen was timed perfectly to take pictures of the one $\mathrm{cm}$ crystals using the Canon PowerShot A2300 digital camera that allows photographs to be taken as close as 3 inches to the crystals. These pictures provide an especially good means to closely observe the morphology of the platy crystals. Figure 5 shows six or seven platy crystals of Viburnum galena. It is clear in this photograph that the plates consist of two portions suggesting that they are twinned crystals. Figure 6 indicates further that the twins are penetration twins. Some of the crystals exhibit indentations along their margins (Figure 7), a characteristic feature shown by spinel twins. It is concluded that the Viburnum platy galena crystals are spinel twins of octahedral galena. Spinel twins of the octahedron are known to typically form flat crystals with characteristic indentations. 


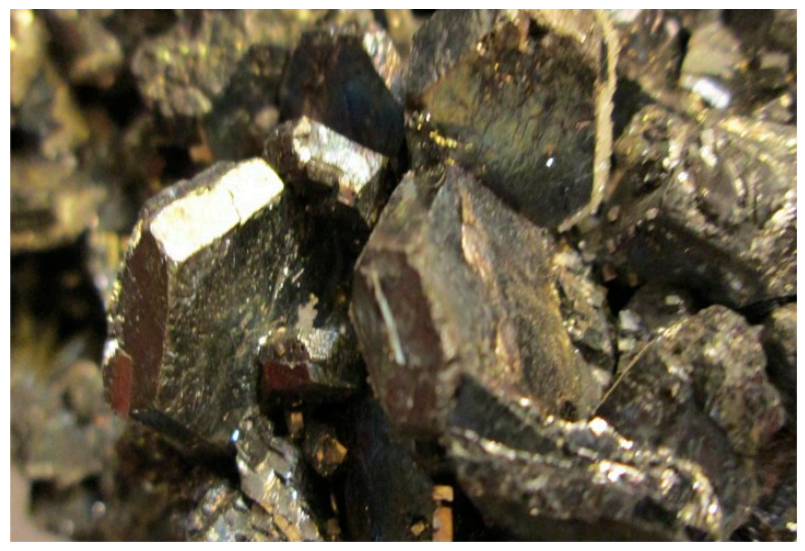

Figure 5. Photograph showing six or seven platy galena crystals. The crystals are about one centimeter in size and they show that the plates consist of two portions suggesting that they are twinned crystals.

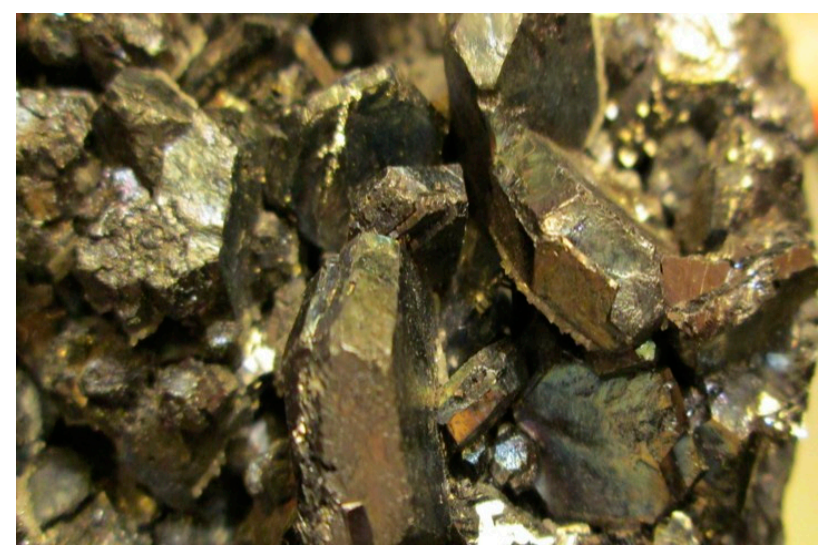

Figure 6. Photograph showing six or seven $1 \mathrm{~cm}$ platy galena crystals indicating that they not only consist of two twin portions but also show that the twins are penetration twins.

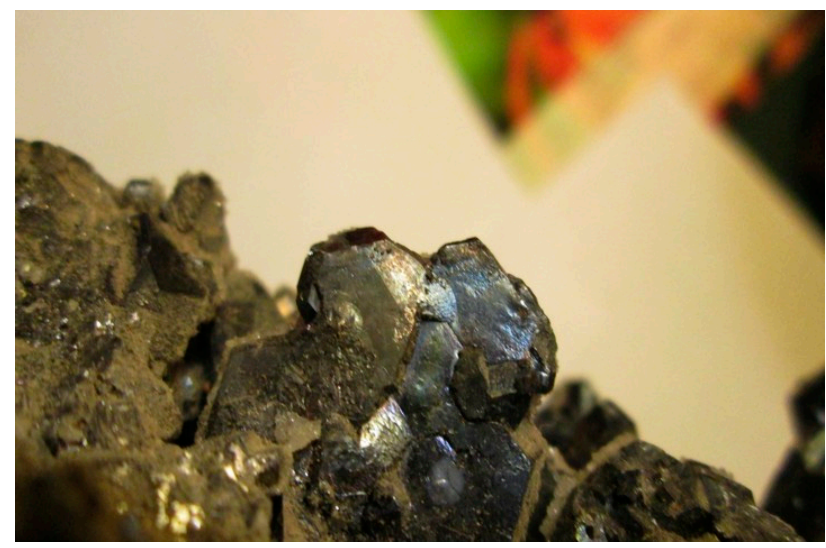

Figure 7. Photograph showing Vibutnum Trend $1 \mathrm{~cm}$ platy galena (center of photograph) with an indentation that is characteristic of spinel-twined crystals.

\section{Paragenetic Position of Viburnum Platy Galena Deposition}

The paragenetic position of deposition of the Viburnum spinel-twinned galena can be determined in the Magmont ore specimen. The determination of paragenetic sequence for open-space deposited ores is straight forward, and involves simply observing which minerals were deposited on top of 
other minerals. Figure 8 shows that spinel-twinned galena was deposited prior to quartz. Figure 9 shows that cubic galena was deposited after and encloses both spinel-twinned galena and quartz. Thus, the spinel-twinned galena was deposited in the paragenetic position of octahedral galena [9]. This further supports the interpretation that the platy crystals are spinel-twinned octahedral galena, rather than a modification of subsequently deposited cubic galena.

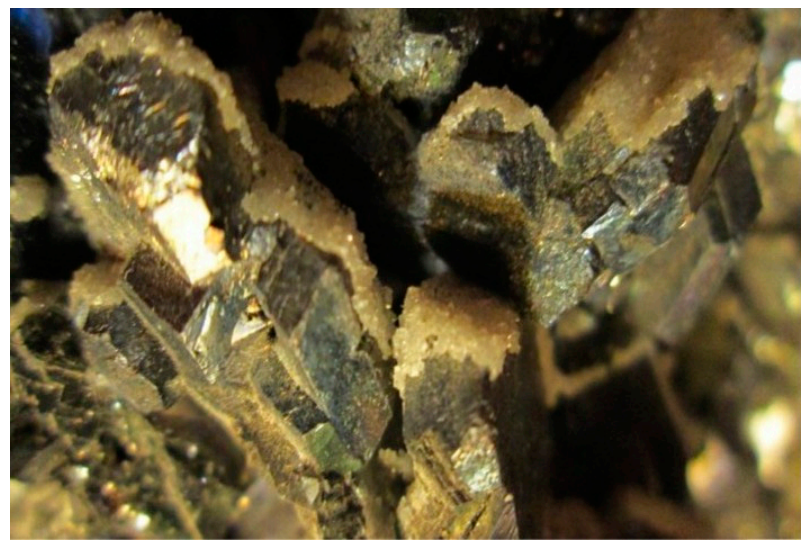

Figure 8. Photograph showing that the $1 \mathrm{~cm}$ platy spinel-twinned galena crystals were deposited prior to quartz in the paragenetic sequence.

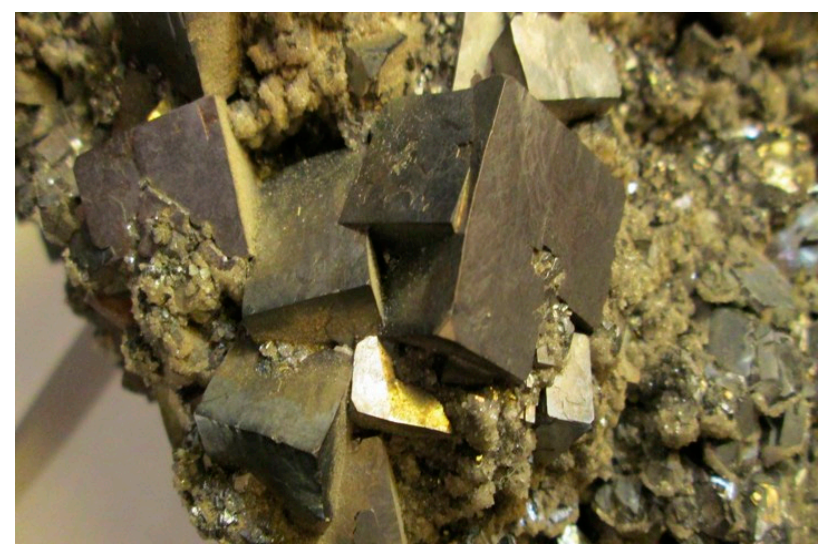

Figure 9. Photograph showing that cubic galena was deposited after and encloses both spinel-twinned galena and quartz. This shows that the spinel-twinned galena was deposited in the paragenetic position of octahedral galena. The galena cubes are about $2 \mathrm{~cm}$ across.

\section{Spinel-Twinned Octahedral Galena from Germany, Russia, Bulgaria, and Mexico}

Although there is rare notation of spinel-twinned galena crystals in the geological literature, mineral dealers have posted pictures on the internet of spinel-twinned galena from Germany, Russia, Bulgaria, and Mexico. The character of the occurrence of spinel-twinned galena at those localities is briefly noted here.

\subsection{Gonderbach Silver Mine, Germany}

Spinel-twinned galena has been described in the geological literature on the Gonderbach silver mine in Germany [33]. Silver was recovered from pyargyrite associated with sphalerite and abundant galena at the mine. Spinel-twinned galena from Gonderbach has been referred to as "Gonderbach plates" or "Gonderbach twins". The Gonderbach mine is located in northwest Germany in the Province of Westphalia but was closed in 1939 [34]. Many pictures of spinel-twinned galena from the 
Gonderbach mine have been illustrated in the literature, textbooks, and on the internet. Figure 10 exhibits an especially flat spinel-twinned galena from the Gonderbach mine [35]. A detailed discussion of the character and formation of spinel-twinned galena at the Gonderbach mine was given by Kolbe [33].

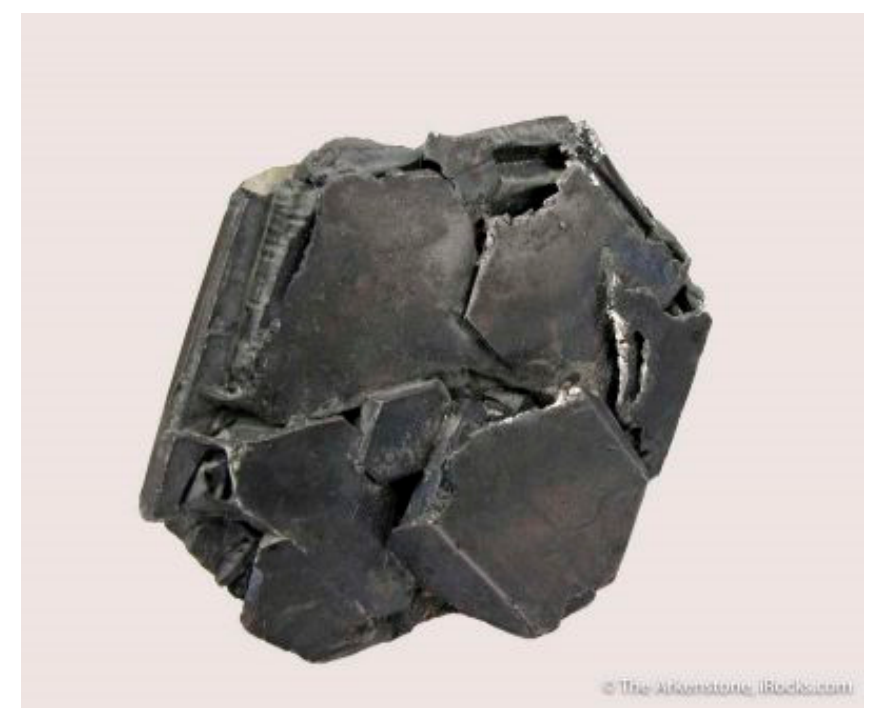

Figure 10. Strongly flattened spinel-twinned galena "Gonderback twin" from Gonderback mine, Germany [35].

\subsection{Dalnegorsk Pb-Zn Mine, Russia}

The Dalnegorsk $\mathrm{Pb}-\mathrm{Zn}$ mine in Russia is a large skarn deposit in extreme southeastern Russia near the border with China. Figure 11 shows the flat character of the spinel-twinned galena from Dalnegorsk. The photograph in Figure 11 is from http:/ / www.minfind.com and posted on the minfind website [36].

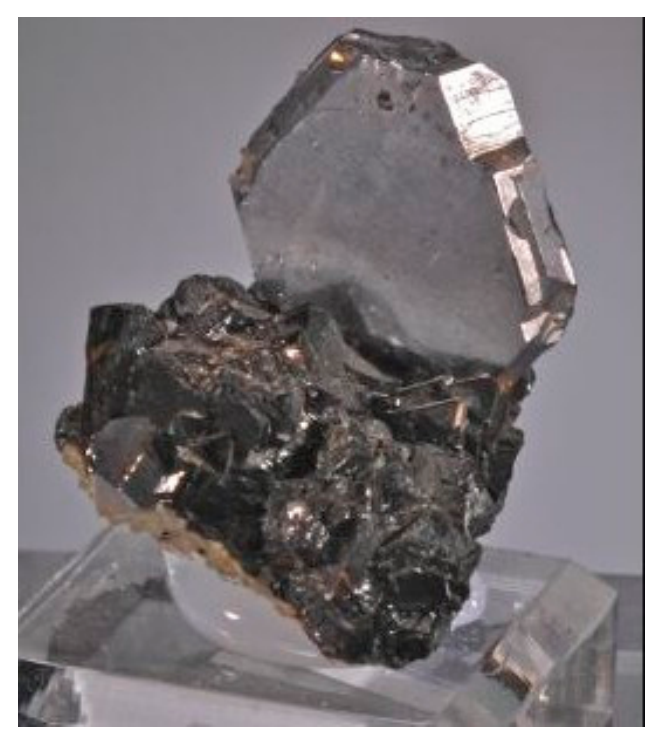

Figure 11. Photograph of spinel-twinned galena from Dalnegorsk, southeast Russia. The photograph illustrates the flat characteristic of spinel twins. Photo from minfind website [36]. 


\subsection{Madan Ore Field, Southern Bulgaria}

The Madan Ore Field in southern Bulgaria comprises a district of 39-40 mines that have worked large $\mathrm{Pb}-\mathrm{Zn}$-Ag deposits and produced $95 \mathrm{MT}$ ore over the last 50 years. The ores are Mn-skarn deposits that were deposited at $350-280{ }^{\circ} \mathrm{C}$, and with ore grades of $2.54 \%$ lead and $2.10 \%$ zinc. The platy character of spinel-twinned galena from Maden is shown in Figure 12. The picture is by Walter R. Kellogg and posted on the M \& W website [37].

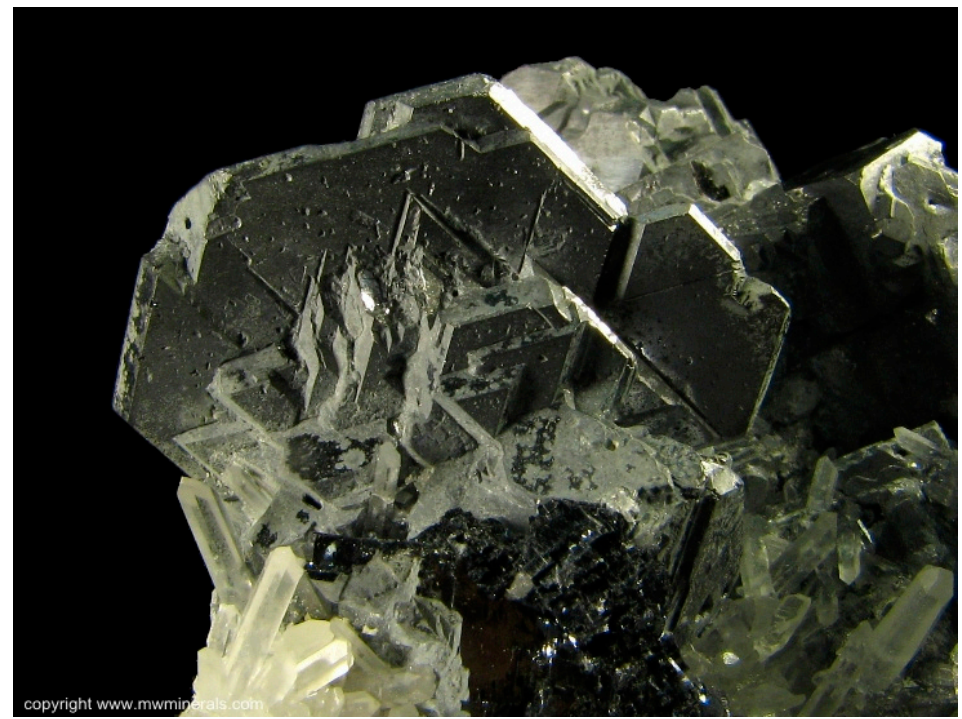

Figure 12. Photograph showing the platy character of spinel-twinned galena from Maden, southern Bulgaria. Photo by Walter R. Kellogg on M\&W Minerals website (37).

\subsection{Naica Lead Mine, Northwestern Mexico}

The Naica lead mine in northwestern Mexico, located in State of Chihuahua, is the largest lead mine in Mexico. The deposit is a lead-zinc skarn deposit that contains $4.9 \%$ lead, $1.1 \%$ zinc, and $1.7 \%$ copper. Figure 13 shows the platy character of Naica spinel-twinned galena. The picture in Figure 13 is courtesy of Dr. Robert Lavinsky [38].

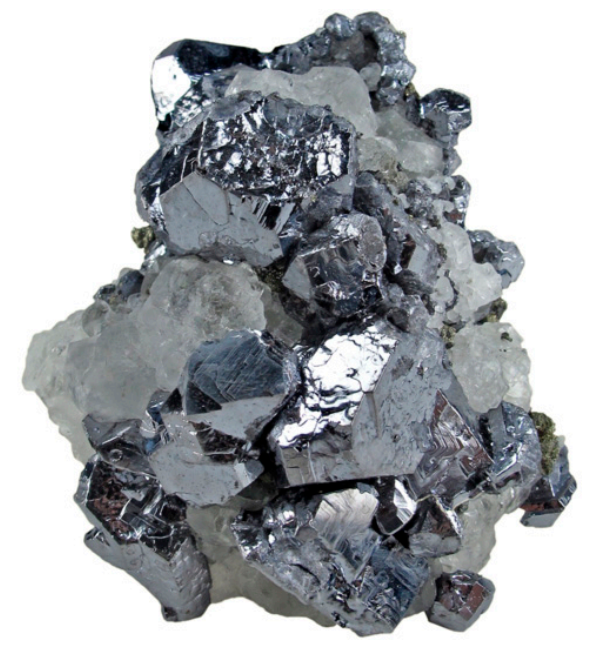

Figure 13. Photograph showing the platy character of spinel-twinned galena from Naica, northwest Mexico. Photo courtesy of Dr. Robert Lavinsky, The Arkenstone [38]. 
The Naica mine is famous for the recent discovery through mine workings in the year 2000 at a depth of 1000 feet of four crystal-containing karst caves that contain huge selenite gypsum crystals. They are said to be the world's largest gypsum crystals, and they are as large as $1.2 \mathrm{~m}$ in diameter and up to $15 \mathrm{~m}$ long. The crystals were deposited from hydrothermal fluids derived from the subjacent magma chamber. The composition of the stable isotopes and the analyses of the fluid inclusions for the gigantic gypsum crystals of Naica are related to the cycles of warm-dry and fresh-wet climatic periods occurring in the region [39]. The crystal caves were featured in a recent National Geographic special.

\section{Other Viburnum Mines that Contain Spinel-Twinned Galena}

Platy or spinel-twinned galena has rarely been observed in mines in the United States. The writer noted a few platy galena crystals in lead ore from one of the mines in the Pine Point District of Canada. A single paper noted that platy galena also occurred rarely in ores from the Black Cloud mine in Colorado.

\section{Role of Trace Elements in the Morphologic Development of Galena}

Having concluded that Viburnum platy galena crystals are spinel-twinned octahedrons, the following questions are then posed: What conditions of the ore depositing fluids led to their deposition? Were elevated amounts of trace elements in the ore fluids responsible? The geological literature on the control of trace elements in ore fluids on the morphology of galena is very limited, and the writer knows only of three communications on the subject. Those communications are: (1) Alpine-type Pb-Zn ores [40]; (2) Madan, Bulgaria Pb-Zn-Ag ores [3]; and (3) Ivan K. Bonev [41] on Madan, Bulgaria $\mathrm{Pb}-\mathrm{Zn}$-Ag ores. These three communications were concerned with the causes of deposition of octahedral as opposed to cubic galena, rather than the effect of trace elements concentrations upon the deposition of spinel-twinned galena.

Erich Schroll [40] proposed that elevated amounts of trace elements Bi (and Ag) in the ore-depositing fluids led to the formation of octahedral galena (vs. cubic galena) in Alpine-type $\mathrm{Pb}-\mathrm{Zn}$ deposits of Bleiberg, Austria; Raibl, Italy; Salafossa, Italy; Mezica, Slovenia. Atanassova and Bonev [42] and Bonev [41] agreed that elevated trace elements, especially Bi and Ag, led to the formation of octahedral galena (Table 1). Although Bonev [41] noted that spinel-twinned galena contained an average of $1318 \mathrm{ppm} \mathrm{Bi}$ and $770 \mathrm{ppm} \mathrm{Ag}$, it was not proposed that the trace element content was responsible for the formation of twinned galena crystals.

Table 1. Maden, Bulgaria Galena trace element means, ppm.

\begin{tabular}{ccccc}
\hline Crystal Form & Ag & Bi & Sb & No. Analyses \\
\hline Cubic & 218 & 4 & 320 & 11 \\
Cubic-Octahedral & 367 & 161 & 373 & 6 \\
Octahedral-Cubic & 566 & 1358 & 141 & 4 \\
Octahedral & 6628 & 8700 & 110 & 1 \\
Spinel Twins & 770 & 1318 & 218 & 6 \\
\hline Data from Ivan K. Bonev [41] Mineralogy and Petrology, Sofia, Bulgaria.
\end{tabular}

The present writer earlier compiled information on the trace element contents of Viburnum cubic and octahedral galena crystals [43,44]. Data from that source on the $\mathrm{Ag}, \mathrm{Bi}$, and $\mathrm{Sb}$ trace contents of cubic and octahedral Viburnum galena are given in Table 2. It is clear that both the Bi and Ag contents of Viburnum galena are much lower than the contents of those trace elements in the Maden galena. Furthermore, octahedral galena contains less Bi and Ag than cubic galena. These data strongly suggest that the trace element content of the ore-depositing fluids in the Viburnum Trend did not control the morphology of Viburnum galena crystals. 
Table 2. Viburnum Trend galena trace element means, ppm.

\begin{tabular}{ccccc}
\hline Crystal Form & Ag & Bi & Sb & No. Analyses \\
\hline Cubic & 88 & 50 & 189 & 186 \\
Octahedral & 18 & n.d. & 241 & 7 \\
\hline \multicolumn{5}{c}{ Data from Hagni [43]. }
\end{tabular}

To investigate the possible role of trace element concentrations upon the formation of spinel-twinned Viburnum galena, a single crystal of the spinel-twinned galena and a crystal of the cubic galena from the same Magmont specimen were analyzed for their trace element concentrations. The results are shown in Table 3. The spinel-twinned Viburnum octahedral galena contains no more Bi and less Ag than the Viburnum cubic galena, and the trace element concentrations for both forms of Magmont galena are exceedingly low. It is concluded that the formation of spinel-twinned galena in the Viburnum Trend was not controlled by trace element concentrations.

Table 3. Trace element means of Pete Sweeney specimen, ppm.

\begin{tabular}{ccccc}
\hline Crystal Form & Ag & Bi & Sb & As \\
\hline Cubic & 5.5 & $<2$ & 97 & 2 \\
Octahedral & 3.1 & $<2$ & $<2$ & $<2$ \\
\hline
\end{tabular}

The two galena crystals from the Viburnum Trend spinel-twinned galena specimen (Table 3) were ground in an agate pestle and agate mortar, and then analyzed by inductively coupled plasma mass spectrometry (ICP-MS) by the commercial firm Acme Analytical Laboratories of Vancouver, British Columbia, Canada. Both crystals were entirely consumed in the process. The crystals selected were deposited in open space, they were not intergrown with other minerals, and they were not coated by other minerals. The large trace element database (Table 2) was compiled by the present writer from diverse analyses reported by many investigators of Viburnum ores, and it included analyses by ICP-MS, atomic absorption (AA), as well as by microprobe analyses. All of the analyses were conducted on single open-space deposited galena crystals free from associated minerals. All of the investigators reported similar results. Viburnum vug-filling galena is especially pure and does not contain other minerals that would contaminate the results. Furthermore, as a result of the very low temperature at which Viburnum galena was deposited, unlike galena from higher temperature deposits, it does not contain exsolved mineral phases. Numerous ore microscopic (commonly using very high magnifications under oil immersion) and microprobe examinations have not recognized a single exsolved grain in any Viburnum Trend galena. Thus, the trace elements detected in all of the reported analyses are clearly present in the galena in the form of solid solutions, and it seems reasonable to compare the results of Table 3 with those of Table 2.

The spinel-twinned galena crystals differ significantly in several respects from the dendritic galena noted under previous investigations earlier in this paper. Although both forms of galena formed as a result of relatively rapid crystallization from oversaturated ore fluids, dendritic galena is a variation of cubic galena whereas spinel-twinned galena is modification of octahedral galena. Most dendritic galena is very fine-grained, commonly consisting of microscopic-sized crystals, whereas spinel-twinned galena crystals are about $1 \mathrm{~cm}$ in size. Finally, dendritic galena occurs in massive ores commonly associated with colloform sphalerite and skeletal dendritic chalcopyrite, whereas spinel-twinned galena has formed as euhedral crystals in open space vug-lining environments.

\section{Observations by Viburnum Mine Geologists}

After concluding that the platy Viburnum crystals were spinel-twined octahedral galena, the writer communicated with present and past Viburnum mine geologist for further data especially 
on the extent of occurrence of platy galena in the Viburnum mines. Mine geologists consulted included: Larry Nuelle, Bill Clendenin, Bob Dunn, Bruce Ahler, Rick Dingess, Andy Childers, and George Moellering. Information from those individuals indicates that platy galena occurred at about one-half of the Viburnum mines. Platy galena crystals occurred at the Magmont, Buick, Fletcher, Brushy Creek, and Sweetwater mines, but those crystals were not found at Casteel, West Fork, \#27, \#28, and \#29 mines. In addition, Clendenin noted that platy galena crystals at the Sweetwater mine found throughout the mine rather than being in one part of the mine or associated with a special ore type.

\section{Role of Rapid Crystallization in the Formation of Spinel-Twinned Viburnum Galena}

The three deposits with spinel-twinned octahedral galena at Dalnegorsk, Madan, and Naica are skarn-type deposits, and they also are large deposits. Skarn deposits are relatively rapidly deposited as compared with the Mississippi Valley-type (MVT) deposits of the Viburnum Trend. The large size of the deposits would also tend to promote oversaturation of the ore fluids. It is speculated that the Viburnum spinel-twinned galena crystals formed as a result of local rapid crystallization from over-saturated ore fluids. The lead cations and sulfur anions in their rush to the crystal faces from the over-saturated ore fluids resulted in an error in crystallization.

\section{Summary and Conclusions}

It is concluded that the Viburnum platy galena crystals are spinel-twinned octahedral crystals. Paragenetic observations shoe that the spinel-twinned Viburnum octahedral galena crystals were deposited prior to quartz and cubic galena in the mineral paragenetic sequence, that is, they were deposited in the octahedral position. The spinel-twinned Viburnum octahedral galena crystals are present in only half of Viburnum Trend mines, namely, Magmont, Buick, Fletcher, Brushy Creek, and Sweetwater. The Viburnum platy galena crystals are similar in morphology to spinel-twinned galena crystals in Pb-Zn deposits at Gonderbach (NW Germany), Dalnegorsk (SE Russia), Madan (Southern Bulgaria), and Naica (Chihuahua, Mexico). Three of those mines are large skarn deposits in which galena was deposited much more rapidly than in typically more slowly deposited MVT ores. It is concluded that the Viburnum Trend spinel-twinned galena formed by rapid crystallization from ore fluids that were locally oversaturated with respect to lead and sulfur.

Acknowledgments: The writer wishes to acknowledge Pete Sweeney, former chief geologist at the Magmont mine, and Mrs. Sweeney, widow of Pete Sweeney, for their contribution of the special spinel-twinned galena-bearing Magmont mine specimen to the mineral museum in the Department of Geosciences and Geological and Petroleum Engineering at the Missouri University of Science and Technology, Rolla, Missouri. Without their contribution the research reported here could not have been carried out. The writer also wishes to thank the three anonymous reviewers for their thoughtful feedback that significantly improved this scientific communication.

Conflicts of Interest: The authors declare no conflict of interest.

\section{References}

1. Mavrogenes, J.A.; Hagni, R.D.; Dingess, P.R. Mineralogy, paragenesis, and mineral zoning of the West Fork mine, Viburnum Trend, southeast Missouri. Econ. Geol. 1992, 87, 113-124. [CrossRef]

2. Kisvarsanyi, G. The role of the Precambrian igneous basement in the formation of the stratabound lead-zinc-copper deposits in southeast Missouri. Econ. Geol. 1977, 72, 435-442. [CrossRef]

3. Cavender, B.D.; Shelton, K.L.; Schiffbauer, J.D. An atypical orebody in the Brushy Creek mine, Viburnum Trend, MVT district, Missouri: Early Cu-(Ni-Co)-Zn-rich ores at the Lamotte Sandstone/Bonneterre Dolomite contact. Econ. Geol. 2016, 111, 259-269. [CrossRef]

4. Gerdemann, P.E.; Myers, H.E. Relationships of carbonate facies patterns in ore distribution and to ore genesis in the Southeast Missouri Lead District. Econ. Geol. 1972, 67, 426-433. [CrossRef]

5. Appold, M.S.; Garven, G. The hydrology of ore formation in the southeast Missouri district: Numerical models of topography-driven fluid flow during the Ouachita Orogeny. Econ. Geol. 1999, 94, 913-936. [CrossRef] 
6. Gregg, J.M.; Shelton, K.L. Minor and trace element distribution in the Bonneterre Dolomite (Cambrian), Southeast Missouri: Evidence for possible multiple basin fluid sources and pathways during lead-zinc mineralization. Geol. Soc. Am. Bull. 1989, 101, 163-186. [CrossRef]

7. Leach, D.L.; Rowan, E. Genetic between Ouachita Fold Belt tectonism and the Mississippi Valley-type Pb-Zn deposits of the Ozarks. Geology 1986, 14, 931-934. [CrossRef]

8. Leach, D.L.; Taylor, R.D.; Fey, D.L.; Diehl, S.F.; Saltus, R.W. A Deposit Model for Mississippi Valley-Type Lead-Zinc Ores, Chapter A of Mineral Deposit Models for Resource Assessment; U.S. Geological Survey Scientific Investigations Report 2010-5070-A; U.S. Geological Survey: Reston, VA, USA, 2010; p. 52.

9. Hagni, R.D. Mineral paragenetic sequence of the lead-zinc-copper-cobalt-nickel ores of the Southeast Missouri Lead District, U.S.A. In Mineral Parageneses; Craig, J.R., Hagni, R.D., Kiesl, W., Lange, I.M., Petrovskaya, N.V., Shadlun, T.N., Udubasa, G., Augustithis, S.S., Eds.; Theophrastus Publications S.A.: Athens, Greece, 1986; pp. 90-132.

10. Hagni, R.D. Ore microscopy, paragenetic sequence, trace element content, and fluid inclusion studies of the copper-lead-zinc deposits of the Southeast Missouri Lead District. In Proceedings of the International Conference on Mississippi Valley Type Lead-Zinc Deposits, Rolla, MO, USA, 2 October 1982.

11. Appold, M.S. Determination of Zn Concentrations in Ore Fluids from Solid Solutions in Calcite: Application to Carbonate-Hosted Base Metal Ore Deposits; Seminar Abstract; Department of Geosciences and Geological and Petroleum Engineering, Missouri University of Science and Technology: Rolla, MO, USA, 2018.

12. Brannon, J.C.; Podosek, F.A.; Viets, J.G.; Leach, D.L.; Goldhaber, M.; Rowan, E.L. Strontium isotopic constraints on the origin of ore-forming fluids of the Viburnum Trend, southeast Missouri. Geochem. Cosmochem. Acta 1991, 55, 1407-1419. [CrossRef]

13. Hagni, R.D. Possible causes for significant variations in chemical and mineralogical compositions among the major ore districts in the Mississippi Valley: Tri-State Zinc District, Southeast Missouri Lead District, and Southern Illinois-Kentucky Fluorite District. Illinois State Geological Survey Circular. In Proceedings of the 47th Forum on the Geology of Industrial Minerals, Champaign, IL, USA, 15-17 May 2011; Lasemi, Z., Ed.; Illinois State Geological Survey: Champaign, IL, USA, 2015; Volume 587, pp. 67-76.

14. Hagni, R.D. Ore microscopy and paragenetic sequence of early bornite ores in the Southeast Missouri Lead District. In Proceedings of the 7th Quadrennial IAGOD Symposium, Luleå, Sweden, 18-22 August 1986; Zachariasson, E., Ed.; E. Schweizerbart'sche Verlagsbuchhandlung: Stuttgart, Germany, 1988; pp. 167-170.

15. Hagni, R.D. Mineralogy and textures of bornite ores in the Sweetwater Mine, Viburnum Trend, Southeast Missouri. Abstracts with Programs. In Proceedings of the 44th Annual Meeting North-Central Geological Society of America, Branson, MO, USA, 11-13 April 2010; Missouri University of Science and Technology: Rolla, MO, USA, 2014.

16. Hagni, R.D.; Sun, J. Ultra fine-grained shale-hosted Pb-Zn ores, Viburnum Trend, USA. In Proceedings of the Fifth Biennial SGA meeting and the Tenth Quadrennial IAGOD Symposium, London, UK, 22-25 August 1999; Stanley, C.J., Ed.; A. A. Balkema: Rotterdam, The Netherlands, 1999; pp. 155-158.

17. Sun, J.; Hagni, R.D.; Dunn, R.G., Jr. Unusual, rapidly precipitated, fine-grained, dendritic-textured, shale-hosted, copper-lead ores, Viburnum Trend, Southeast Missouri. In Studies on Ore Deposits, Mineral Economics, and Applied Mineralogy: With Emphasis on Mississippi Valley-Type Base Metal and Carbonatite-Related Ore Deposits; Hagni, R.D., Ed.; University of Missouri-Rolla: Rolla, MO, USA, 2001.

18. Voss, R.L.; Hagni, R.D. The application of cathodoluminescence microscopy to the study of sparry dolomite from the Viburnum Trend, southeast Missouri. In Mineralogy_Applications to the Minerals Industry, Proceedings of the Paul F. Kerr Memorial Symposium, New York, NY, USA, 28 February 1985; Hausen, D.M., Kopp, O.C., Eds.; Society of Mining Engineers: New York, NY, USA, 1985; Chapter 5; pp. 51-68.

19. Voss, R.L.; Hagni, R.D.; Gregg, J.M. Sequential deposition of zoned dolomite and its relationship to sulfide mineral paragenesis in the Viburnum Trend, southeast Missouri, Special Issue on The Relationships Between Dolomitization, Basin Development, and Mississippi Valley-Type Ore Deposits. Carbonates Evaporites 1989, 4, 195-209. [CrossRef]

20. Gregg, J.M. Regional epigenetic dolomitization in the Bonneterre Dolomite (Cambrian), Southeastern Missouri. Geology 1985, 13, 503-506. [CrossRef]

21. Rowan, E.L. Carhodoluminescent zonation of hydrothermal cements: Relationship to Mississippi Valley-Type $\mathrm{Pb}-\mathrm{Zn}$ mineralization in southern Missouri and northern Arkansas. In Process Mineralogy VI; Hagni, R.D., Ed.; The Metallurgical Society: Warrendale, PA, USA, 1986; pp. 69-87. 
22. Hagni, R.D. The Southeast Missouri Lead District: A review. In Mississippi Valley-Type Mineralization of the Viburnum Trend; Society of Economic Geologists Guidebook 5; Hagni, R.D., Coveney, R.M., Eds.; Citizen Printing Co., Inc.: Fort Collins, CO, USA, 1989; pp. 12-57.

23. Hagni, R.D. The copper-lead-Zinc ore deposits of the Viburnum Trend, Southeast Lead District Missouri: Their mineralogy, ore textures, ore controls, and origin. In Proceedings of the Symposium on the Geology of the Kapadokya Region, Nigde, Turkey, 17-20 October 2007; pp. 184-189.

24. Hagni, R.D. The ore deposits of the South-East Missouri cobalt-copper-lead-zinc district: Mineralogy, ore textures, applied mineralogy and ore controls. In Proceedings of the 9th International Congress for Applied Mineralogy, Brisbane, Australia, 8-10 September 2008; Gu, Y., Ed.; Australasian Institute of Mining and Metallurgy: Carlton, Australia, 2008; pp. 29-38.

25. Hagni, R.D.; Trancynger, T.C. Sequence of deposition of the ore minerals at the Magmont Mine. Econ. Geol. 1977, 72, 451-464. [CrossRef]

26. Lasmanis, R. Galena from Mississippi Valley-type deposits. Rocks Miner. 1989, 64, 10-34. [CrossRef]

27. Lasmanis, R. Tri-State and Viburnum Trend Districts: An overview. Rocks Miner. 1997, 72, 400-419. [CrossRef]

28. Fennel, M.J.; Hagni, R.D. Mineralogy, Paragenetic sequence, and mineral zoning at the Magmont-West Mine, Viburnum Trend, Southeast Missouri Lead District. In Carbonate-Hosted Lead-Zinc Deposits; Sangster, D.F., Ed.; Society of Economic Geologists: Littleton, CO, USA, 1997; pp. 597-610.

29. Sun, Y.; Hagni, R.D.; Walker, W.T. Characterization of cuboctahedral galena and its areal distribution. In $\mathrm{Pb}-\mathrm{Zn}$-Cu Ores at the Sweetwater Mine, Viburnum Trend, Southeast Missouri. Carbonate-Hosted Lead-Zinc Deposits; Sangster, D.F., Ed.; Society of Economic Geologists: Littleton, CO, USA, 1997; pp. 587-596.

30. Sun, Y.; Hagni, R.D.; Walker, W.T.; Wagner, R.J. Classification and areal distributions of galena morphologies in a Mississippi Valley-type deposit, Sweetwater mine, Viburnum Trend, Southeast Missouri, U.S.A. In Proceedings of the Ninth IAGOD Symposium, International Association on the Genesis of Ore Deposits, Beijing, China, 12-18 August 1994; Hagni, R.D., Ed.; Schweizerbart'sche Verlagsbuchhandlung: Stuttgart, Germany, 1998; pp. 131-142.

31. Clendenin, C.W. Suggestions for interpreting Viburnum Trend mineralization based on field studies at Ozark Lead Company, Southeast Missouri. Econ. Geol. 1977, 72, 465-473. [CrossRef]

32. Clendenin, C.W.; Rickman, D.L. Suggestions for interpreting Viburnum Trend mineralization based on field studies at Ozark Lead Company, Southeast Missouri: II. Precipitation models. South-Central Section Geological Society of America Abstracts with Programs. (Abstract). Econ. Geol. 1979, 72, 465-473. [CrossRef]

33. Kolbe, E. Die bleierziagerstasse Gonderbach bei Laasphe und ihre entstehung. Neues Jahrb. Miner. 1925, 30, 286-333.

34. Gonderbach Mine, Fischelbach, Bad Laasphe, North Rhine-Westphalia, Germany. Available online: https: / / www.mindat.org/loc-11415.html (accessed on 24 January 2018).

35. Image of Spinel-Twinned Galena from Gonderbach Mine in Germany. Available online: https://www. mindat.org/loc-11415.html (accessed on 24 January 2018).

36. Image of Spinel-Twinned Galena from Dalnagorsk Mine in Russia. Available online: http://www.minfind. com/mineral-142412.html (accessed on 27 December 2012).

37. Kellogg, W.R. Mineral Specimen \#215 Spinel Twins Galena. Available online: http:/ / www.mwminerals. com/m215_Spinel_Galena_Bulgaria.html (accessed on 27 December 2012).

38. The Arkenstone. Available online: www.iRocks.com (accessed on 28 December 2012).

39. Garofalo, P.S.; Fricker, B.M.; Gunther, D.; Forti, P.; Mercuri, A.; Loreti, M.; Capaccioni, B. Climatic control on the growth of gigantic gypsum crystals within hypogenic caves (Naica mine, Mexico). Earth Planet. Sci. Lett. 2010, 289, 560-569. [CrossRef]

40. Schroll, Erich; Universitat Wien, Vienna, Austria. Personal communication, 1995.

41. Bonev, I.K. Crystal habit of Ag-, Sb- and Bi-bearing galena from the $\mathrm{Pb}-\mathrm{Zn}$ ore deposits in the Rhodope Mountains. Geochem. Mineral. Petrol. 2007, 45, 1-18.

42. Atanassova, R.; Bonev, I.K. Two crystallographically different types of skeletal galena associated with colloform sphalerite. Geochem. Mineral. Petrol. 2006, 44, 1-88. 
43. Hagni, R.D. Minor elements in Mississippi Valley-Type ore deposits. In Cameron Volume on Unconventional Mineral Deposits; Shanks, W.C., III, Eds.; Society of Mining Engineers: New York, NY, USA, 1983; pp. 71-88.

44. Hagni, R.D. The mineralogy of minor and trace elements in the Co-Ni-Cu-Pb-Zn ores of the Viburnum Trend, southeast Missouri: Ag, Cd, Ge, Ga, Co, Ni, As, Sb, Bi minerals. In Minor Elements 2000: Processing and Environmental Aspects of As, Sb, Se, Te, and Bi; Young, C., Ed.; Society of Mining, Metallurgy, and Exploration Inc.: Littleton, CO, USA, 2000; pp. 181-190.

(C) 2018 by the author. Licensee MDPI, Basel, Switzerland. This article is an open access article distributed under the terms and conditions of the Creative Commons Attribution (CC BY) license (http:/ / creativecommons.org/licenses/by/4.0/). 